\title{
Feeding level and diet type during the wean-to-estrus interval on the reproductive performance of sows
}

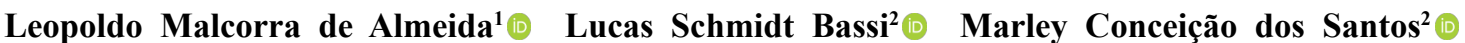 Uislei Antônio Dias Orlando ${ }^{3}$ (๑) Márcio Antônio Dornelles Gonçalves ${ }^{4} \odot$ Alex Maiorka $^{5^{*}} \odot$ Antônio João Scandolera ${ }^{5}$ (우}

\begin{abstract}
${ }^{1}$ Programa de Pós-graduação em Ciências Veterinárias, Universidade Federal do Paraná (UFPR), Curitiba, PR, Brasil. ${ }^{2}$ Programa de Pós-graduação em Zootecnia, Universidade Federal do Paraná (UFPR), Curitiba, PR, Brasil.

${ }^{3}$ Genus PIC, Hendersonville, TN, United States.

${ }^{4}$ Swineit, Clearwater, FL, United States.

${ }^{5}$ Departamento de Zootecnia, Universidade Federal do Paraná (UFPR), 80035-050, Curitiba, PR, Brasil. E-mail: amaiorka@ufpr.br. ${ }^{*}$ Corresponding author.

ABSTRACT: This study was conducted to evaluate how the amount and type of diet consumed during the wean-to-estrus interval (WEI) affects reproductive performance and WEI duration in sows. A total of 542 sows were distributed into the following treatment groups based on a $2 \times 2$ factorial design: feed amount during WEI (2.75 or $3.75 \mathrm{~kg} /$ day) and diet (gestation [G] or lactation [L]) groups. Dietary treatments were as follows: high supply of $G$ diet $(G H)$, low supply of $G$ diet $(G L)$, high supply of $L$ diet $(L H)$, and low supply of $L$ diet $(L L)$. Sows were randomly allocated to groups according to their body score Caliper and birth order. There was an interaction $(P<0.05)$ between the factors for WEI duration, which was 0.2 days shorter in the GH and LL groups than in the other groups. No difference was observed between treatments (P>0.05) for the birth rate, total births, stillbirths, or total litter weight. There was a trend $(P<0.10)$ toward a higher rate of live births in sows fed with $G$ diet and sows receiving a low diet supply, with an average of $91.95 \%$ for both groups. In addition, there was a positive trend $(P<0.10)$ for live weight of the litter, where GH and LL treatments resulted in higher birth weight (17.9 and $17.7 \mathrm{~kg}$, respectively) than other treatments. In conclusion, a supply of $3.75 \mathrm{~kg} / \mathrm{day}$ or the use of a more energetic feed (lactation) during the WEI did not improve the reproductive performance of the subsequent cycle of sows in good body condition. Key words: feed intake, postweaning, swine nutrition.
\end{abstract}

Efeito da quantidade e tipo de dietas durante o intervalo desmame-estro sobre o desempenho reprodutivo de matrizes suínas

RESUMO: Este experimento foi conduzido com o objetivo de avaliar os efeitos da quantidade e tipo de dieta consumida durante o intervalo desmame-estro (IDE) sobre o desempenho ao parto subsequente e tempo de IDE de fêmeas suínas. Foram utilizadas 542 fêmeas, distribuídas em um delineamento fatorial $2 \times 2$ com duas quantidades de alimento fornecido durante o IDE $(2,75 \mathrm{ou} 3,75 \mathrm{~kg} /$ dia) e dois tipos de dieta (gestação - G ou lactação - L), sendo: Alto fornecimento de dieta $G(G A)$, menor fornecimento de $G$ (GM), alto fornecimento de L (LA) e menor fornecimento de L (LM). As fêmeas foram aleatoriamente distribuídas entre os tratamentos em blocos de acordo com o escore corporal Caliper e ordem de parto. Houve interação para tempo de IDE $(P<0,05)$ entre a quantidade de ração e o tipo da dieta consumida durante o periodo, o qual foi 0,2 dias mais curto nos grupos GA e LM. Não houve diferença entre os tratamentos (P>0,05) sobre a taxa de parto, total de nascidos, natimortos e peso total da leitegada. Houve uma tendência para maior taxa de nascidos vivos (P<0,10) nas fêmeas que consumiram a dieta $G$, e nas fêmeas que receberam o menor fornecimento de ração, com média de 91,95\%, para ambos os fatores. Além disso, foi observada tendência positiva $(P<0,10)$ para o peso vivo da leitegada, em que GA e LM apresentaram maior peso ao nascer $(17,9$ e 17,7 kg, respectivamente). Em conclusão, o fornecimento de $3,75 \mathrm{~kg} /$ dia, ou o uso de uma dieta mais energética (lactação) durante o IDE, não melhora o desempenho reprodutivo do ciclo subsequente de fêmeas suínas em boa condição corporal.

Palavras-chave: consumo, pós-desmame, nutrição suína.

\section{INTRODUCTION}

Weaning in industrial pig farming is a critical period in animal management. It is characterized by high stress, and strongly influences the health and productivity of piglets. In addition, weaning is stressful for females, in whom lactation is interrupted abruptly after peak milk production is reached, and who are separated from their litter, and transferred to facilities with different feeding and handling conditions. Despite being a complex process, the change from anestrus to a cyclical phase is expected to happen over few days, with a weaningto-estrus interval (WEI) of 4-6 days in commercial sows (POLEZE et al. 2006; JONG et al., 2013). This period can be influenced by several factors, which 
are related to the sow, birth order (BO), and genetics, or to the management used for the farm animals, such as duration of lactation and weight loss during the period.

Reproductive productivity of the sow can also be affected by nutrition, such as the amount of feed eaten by the animal during WEI. KING \& WILLIAMS (1984) reported an increase of approximately $12 \%$ in ovulation rate and litter size in primiparous sows eating $4 \mathrm{~kg}$ /day during WEI, compared to females eating only $1.5 \mathrm{~kg} /$ day. In contrast, other studies have shown that the amount of feed consumed during WEI has no effect on the reproductive performance of multiparous females (BROOKS et al., 1975; TRIBBLE \& ORR, 1982). AHERNE \& KIRKWOOD (1985) suggested that increased feed intake during WEI only benefitted primiparous sows or females who had high weight loss and decreased body condition during lactation. Thus, nutritional strategies used during the WEI included the use of more energetic diets and/or increased feed supply, with the objective of recovering reproductive performance.

However, with the shorter WEI that is currently implemented, we hypothesized that a greater feed supply $(3.75 \mathrm{~kg} /$ day $)$ and/or a more energetic diet (lactation) no longer influence the swine female in subsequent reproductive performance. Recent data on the benefits of increased feed and type ingested by the modern sows, selected for a shorter WEI, are limited. GRAHAM et al. (2015) and GIANLUPPI et al. (2020) reported no influence of increased consumption of both gestation and lactation feeds on the WEI or on improved performance after the period.

Therefore, the objective of this study was to evaluate the effect of two amounts (2.75 and $3.75 \mathrm{~kg} /$ day) and two types of feed (gestation and lactation) provided in the WEI of swine females on their reproductive performance and WEI duration.

\section{MATERIALS AND METHODS}

The study included 542 PIC Camborough sows from weaning to the subsequent farrowing. The sows were housed in individual cages in the gestation area $(220 \times 61 \mathrm{~cm})$ on the day of weaning. They were divided into blocks by birth order (first farrowing [BO1], second farrowing [BO2], third farrowing or more $[\mathrm{BO} 3+]$, with a mean and standard error of the mean [SEM] of $4.6 \pm 0.19$ ) and Caliper score (125 , with a mean and SEM of $13 \pm 1.97$ ), and then randomly distributed into four $2 \times 2$ factorial design treatments with two amounts and two types of feeds during the WEI. The Caliper score of the females was assessed following the methodology by KNAUER \&
BAITINGER (2015) at the end of the maternity period ( \pm 21 days, before the experimental feeding period).

During the WEI, the sows were manually fed with a bran lactation (L) or a bran gestation feed $(\mathrm{G})$, in two quantities: $3.75 \mathrm{~kg} /$ day $(\mathrm{H})$ or $2.75 \mathrm{~kg} /$ day (L), weighed in a digital scale (Toledo Light Prix III ${ }^{\circledR}$ ) (Table 1), and supplied in individual feeders twice a day (half in the morning and half in the afternoon). Every day, surplus experimental feed was collected, weighed on a digital scale (Toledo Light Prix III ${ }^{\circledR}$ ), and the mean and total feed consumption in the period were determined per female.

The following treatments were formed by the type and amount of feed supplied: $\mathrm{GH}$ - gestation feed, $3.75 \mathrm{~kg} /$ day; GL - gestation feed, $2.75 \mathrm{~kg} /$ day; $\mathrm{LH}$ - lactation feed, $3.75 \mathrm{~kg} /$ day; and LL - lactation feed, $2.75 \mathrm{~kg} /$ day. The animals were given ad libitum access to water.

Estrus was detected by lumbar pressure and exposure to an adult male once a day, always in the morning. The period immediately after estrus identification was designated hour zero. Then, all females underwent artificial heterospermic post-cervical insemination (PCI) (50 mL AGPIC-415 inseminating dose with 1 billion spermatozoids) at 0,12 and, if the females responded to male exposure, $24 \mathrm{~h}$ after estrus identification, with a mean of $2.8 \mathrm{PCI} /$ female.

After finishing the experimental feeding, which occurred from weaning day to estrus identification, sows received the same amount of gestation feed: $1 \mathrm{~kg}$ /day during the insemination period and $2.3 \mathrm{~kg} /$ day from the day after the last insemination up to 30 days of gestation, followed by $1.8 \mathrm{~kg}$ /day until farrowing, regardless of $\mathrm{BO}$ and body condition. Between days 15 and 70 of gestation, the return to estrus was verified daily (morning and afternoon), and finally, at day 112 of gestation, the females were transferred to the maternity area.

The temperature of the area during the experiment was between 20.6 and $30^{\circ} \mathrm{C}$.

At the end of farrowing, the numbers of live births, stillbirths, and mummified fetuses were recorded. Litter weight (total births and live births) was recorded within $12 \mathrm{~h}$ after farrowing. The following were calculated using the data recorded: live birth rate $(\mathrm{LB})=\%$ birth rate $(\mathrm{BR}) \times$ total births (TB) $\times \%$ LB $\times 100$; and mean total birth weight index $=\% \mathrm{BR} \times \mathrm{TB} \times \mathrm{TB}$ mean individual weight, adapted from VANGROENWEGHE et al. (2016).

The data were analyzed using generalized linear mixed models with the sows being considered the experimental unit, with $130(\mathrm{GH}), 134(\mathrm{GL}), 136$ (LH), and 141 (LL) females per treatment. Fixed 
Table 1 - Percent composition and calculated nutritional values of gestation and lactation feeds (Natural matter-basis).

\begin{tabular}{|c|c|c|}
\hline Ingredients & Gestation, $\%$ & Lactation, $\%$ \\
\hline Corn & 80.18 & 59.90 \\
\hline Soybean meal & 15.70 & 30.20 \\
\hline Soy oil & 0.00 & 2.00 \\
\hline Sugar & 0.00 & 2.00 \\
\hline Dicalcium phosphate & 1.30 & 1.10 \\
\hline Calcitic limestone & 1.00 & 1.10 \\
\hline Salt & 0.60 & 0.50 \\
\hline Gestation vitamin premix $^{1}$ & 0.13 & 0.00 \\
\hline Lactation vitamin premix ${ }^{2}$ & 0.00 & 0.12 \\
\hline Gestation microminerals ${ }^{3}$ & 0.22 & 0.00 \\
\hline Lactation microminerals ${ }^{4}$ & 0.00 & 0.20 \\
\hline Adsorbent & 0.20 & 0.20 \\
\hline Lysine & 0.11 & 0.63 \\
\hline Enzyme complex & 0.00 & 1.00 \\
\hline DL-Methionine & 0.03 & 0.05 \\
\hline Threonine & 0.01 & 0.16 \\
\hline Choline chloride 60 & 0.12 & 0.13 \\
\hline Kaolin & 0.27 & 0.21 \\
\hline Others & 0.12 & 0.49 \\
\hline \multicolumn{3}{|c|}{ 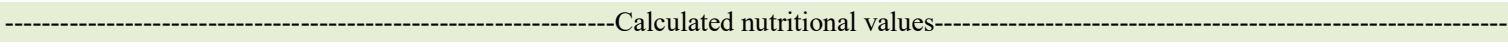 } \\
\hline Metabolizable energy, $\mathrm{kcal} / \mathrm{kg}$ & 3280 & 3410 \\
\hline Crude protein, $\%$ & 14.00 & 20.00 \\
\hline Lysine, \% & 0.699 & 1.300 \\
\hline Methionine + cystine, \% & 0.508 & 0.683 \\
\hline Threonine, \% & 0.554 & 0.935 \\
\hline Tryptophan, \% & 0.151 & 0.245 \\
\hline Crude fiber, $\%$ & 2.219 & 2.664 \\
\hline Mineral matter, $\%$ & 5.269 & 5.489 \\
\hline Fat, \% & 3.193 & 4.689 \\
\hline Calcium, \% & 0.850 & 0.900 \\
\hline Available phosphorus, $\%$ & 0.420 & 0.430 \\
\hline
\end{tabular}

${ }^{1}$ Quantity provided per kg of complete feed: Vit. A, 12,870 IU; Vit. D3, 2,600 IU; Vit. E, 85.8 IU; Vit. K3, 5.2 mg; Vit. B2, 12.87 mg; Vit. B12, $52 \mathrm{mcg}$; pantothenic ac., $42.9 \mathrm{mg}$; nicotinic acid-B3, $57.2 \mathrm{mg}$.

${ }^{2}$ Provides per kg of complete diet: Vit. A, 11,880 IU; Vit. D3, 2,400 IU; Vit. E, 79.2 IU; Vit. K3, 4.8 mg; Vit. B2, 11.88 mg; Vit. B12, $48 \mathrm{mcg}$; pantothenic acid, $39.6 \mathrm{mg}$; nicotinic acid, $52.8 \mathrm{mg}$

${ }^{3}$ Provides per kg of complete diet: Se, $0.45 \mathrm{mg}$; Mn, $34.9 \mathrm{mg}$; Cu, $15.39 \mathrm{mg}$; Fe, $182.03 \mathrm{mg} ; \mathrm{Zn}, 135 \mathrm{mg} ; \mathrm{I}, 0.310 \mathrm{mg}$.

${ }^{4}$ Provides per kg of complete diet: Se, $0.48 \mathrm{mg}$; $\mathrm{Mn}, 36.2 \mathrm{mg}$; Cu, $16.3 \mathrm{mg} ; \mathrm{Fe}, 186 \mathrm{mg} ; \mathrm{Zn}, 128 \mathrm{mg}$; I, $0.282 \mathrm{mg}$.

effects included the experimental treatments, random effects, and body condition of the sow, with $\mathrm{BO}$ considered as a covariable.

Feed intake, mean total birth weight, mean live birth weight, individual mean weights, WEI indices, and duration assumed a normal distribution in the analysis of deviations. The total number of piglets born was adjusted assuming a negative binomial distribution in the response, while live births, stillbirths, and mummified fetuses were adjusted using a binomial distribution. Birth rate was adjusted based on a binary distribution. In these cases, the residual assumptions were verified using standardized diagnostics of the studied residues, which were considered satisfied.

Overdispersion was assessed using the Pearson's Chi-square/DF statistic based on maximum probability and was accounted as needed (STROUP, 2012). The final models used for inference were adjusted using the maximum restricted likelihood estimate. Degrees of freedom were estimated using the approach described by KENWARD \& ROGERS (1997).

Statistical models were adjusted using the GLIMMIX procedure of the SAS software (Version

Ciência Rural, v.50, n.12, 2020. 
9.3, SAS Institute Inc., Cary, NC). Results were considered significant when $\mathrm{P} \leq 0.05$ and a trend was considered at $0.05<\mathrm{P} \leq 0.10$.

\section{RESULTS}

Feed intake during the WEI was significantly influenced by the type of $\operatorname{diet}(\mathrm{P}=0.005)$ and the amount supplied $(\mathrm{P}<0.001)$. Animals receiving the $\mathrm{GH}$ feed $(3.75 \mathrm{~kg}$ /day) consumed a mean of $3.3 \mathrm{~kg}$ per day, with a standard deviation of 0.60 and an accumulated consumption of 13.50 $\mathrm{kg} \pm 3.09$. This was statistically significantly higher than the GL group $(2.75 \mathrm{~kg} /$ day $)$, whose mean daily consumption was $2.55 \mathrm{~kg} \pm 0.34$ and the accumulated consumption was $10.76 \mathrm{~kg} \pm 2.84$. Sows receiving the $\mathrm{LH}$ diet consumed a mean of $3.43 \mathrm{~kg} /$ day \pm 0.49 , with an accumulated consumption of $14.73 \mathrm{~kg} \pm$ 3.19 , differing from the LL group, with a mean daily consumption of $2.60 \mathrm{~kg} \pm 0.18$ and accumulated consumption of $10.86 \mathrm{~kg} \pm 2.06$.

There was an interaction $(\mathrm{P}<0.05)$ between the type and amount of feed consumed for WEI duration, in which the duration for the GH and LL groups was shorter than that for the GL and $\mathrm{LH}$ groups (Table 2). There was no difference $(\mathrm{P}>0.05)$ for birth rate, percentage of total births, and stillbirths. However, there was a trend $(\mathrm{P}<0.10)$ for an increasing percentage of live births in females consuming the gestation feed compared with those consuming the lactation feed, and also by the lowest amount of feed ingested compared to the highest $(\mathrm{P}<0.10)$, both induced by differences $(\mathrm{P}<0.05)$ in the percentage of mummified fetuses.
There was no difference $(\mathrm{P}>0.05)$ in the litter weight of total births, mean birth weight index, and live birth index. There was a trend for interaction $(\mathrm{P}<0.10)$ between the type and amount of feed ingested for the total litter weight of live births. Furthermore, the sows ingesting $\mathrm{GH}$ and LL presented heavier litter compared with those of females ingesting GL and LH (Table 3).

\section{DISCUSSION}

Separation of piglets and sows, as well as the sudden change of environment, has a strong influence on the behavior of the litter and the sow during the postweaning period. The stress generated by weaning in the swine female may be one of the factors reducing appetite and leading to high variability in feed intake; this effect was observed in the present study and is consistent with the findings of GIANLUPPI et al. (2020).

This interval is considered to be crucial for nutritional strategies such as the use of more energetic feed and/or increased feed supply, which help the sow recover body reserves lost during lactation, thereby reducing negative effects of body loss on subsequent reproductive performance. However, with the successful selection of a shorter WEI, females present estrus 4-6 days after weaning (POLEZE et al., 2006), a relatively short period compared to the more than 9 days reported in the 1970s (BROOKS \& COLE, 1972). FAHMY \& DUFOUR (1976) reported that positive reproductive performance also depends on a feed intake period of at least 4 days; thus, the short WEI of the contemporary female may

Table 2 - Reproductive performance of swine females (PIC Camborough ${ }^{\circledR}$ ) consuming two feeds (gestation and lactation) and two amounts of feed during the weaning-estrus interval (WEI).

\begin{tabular}{|c|c|c|c|c|c|c|c|c|}
\hline \multirow{2}{*}{$\begin{array}{l}\text { Item Diet } \\
\text { Qtt }(\mathrm{kg})^{1}\end{array}$} & \multicolumn{2}{|c|}{--------Gestation--------- } & \multicolumn{2}{|c|}{--------Lactation--------- } & \multirow[t]{2}{*}{$\mathrm{mSE}^{2}$} & \multicolumn{3}{|c|}{---------------Probability, P------------- } \\
\hline & 3.3 & 2.55 & 3.43 & 2.6 & & Diet x Qtt & Diet & Qtt \\
\hline Number of sows & 130 & 134 & 136 & 141 & & & & \\
\hline Birth rate, $\%$ & 87.1 & 87.0 & 89.2 & 89.2 & 3.2 & 0.967 & 0.438 & 0.973 \\
\hline WEI, days & 4.1 & 4.3 & 4.3 & 4.1 & 0.12 & 0.021 & 0.469 & 0.965 \\
\hline Total births, $\mathrm{n}$ & 15.4 & 15.0 & 15.1 & 15.1 & 0.36 & 0.587 & 0.719 & 0.610 \\
\hline Live births, $\%$ & 91.7 & 92.2 & 89.9 & 91.7 & 1.17 & 0.395 & 0.080 & 0.070 \\
\hline Stillbirths, \% & 6.3 & 6.3 & 6.7 & 5.6 & 1.3 & 0.337 & 0.793 & 0.331 \\
\hline Mummified, $\%$ & 2,8 & 1.5 & 3.4 & 2.7 & 0.45 & 0.261 & 0.004 & 0.003 \\
\hline Live Birth Index, $\mathrm{n}^{3}$ & 1548 & 1488 & 1538 & 1581 & 73 & 0.385 & 0.480 & 0.886 \\
\hline
\end{tabular}

${ }^{1}$ Mean amount of feed consumed.

${ }^{2}$ Mean standard error.

${ }^{3}$ Live birth index is the number of births to 100 females. 
Table 3 - Litter weight and mean litter weight index of sows (PIC Camborough ${ }^{\circledR}$ ) receiving two feeds (gestation and lactation) and two amounts during the weaning-to-estrus interval (WEI).

\begin{tabular}{|c|c|c|c|c|c|c|c|c|}
\hline \multirow{2}{*}{$\begin{array}{l}\text { Item Diet } \\
\text { Qtt }(\mathrm{kg})^{1}\end{array}$} & \multicolumn{2}{|c|}{----Gestation--- } & \multicolumn{2}{|c|}{----Lactation---- } & \multirow[t]{2}{*}{$\mathrm{mSE}^{2}$} & \multicolumn{3}{|c|}{ 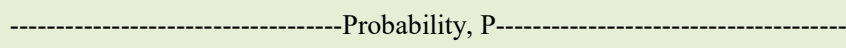 } \\
\hline & 3.3 & 2.55 & 3.43 & 2.6 & & Diet x Qtt & Diet & Qtt \\
\hline \multicolumn{9}{|c|}{ 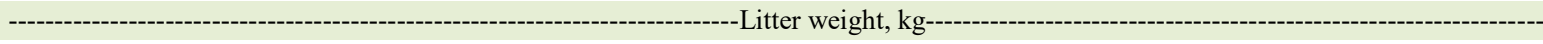 } \\
\hline Total births & 19.0 & 18.1 & 18.6 & 18.8 & 0.4 & 0.160 & 0.750 & 0.382 \\
\hline Live births & 17.9 & 17.1 & 17.2 & 17.7 & 0.4 & 0.084 & 0.877 & 0.653 \\
\hline \multicolumn{9}{|c|}{ - } \\
\hline Total births & 1.26 & 1.21 & 1.25 & 1.27 & 0.03 & 0.156 & 0.400 & 0.578 \\
\hline
\end{tabular}

${ }^{1}$ Mean amount of feed consumed.

${ }^{2}$ Mean standard error.

${ }^{3}$ Live Birth Index is the number of births to 100 females.

not be sufficient to confirm that a higher feed intake or greater nutritional density influences follicular development and subsequent performance.

In the previous strains, increased feed intake sometimes impacted WEI duration, mainly in first-farrowing sows, reducing the WEI in 12 days in primiparous sows ingesting $3.6 \mathrm{~kg} /$ day compared to sows ingesting $1.8 \mathrm{~kg} /$ day (BROOKS \& COLE, 1972). The same effect was observed in the present study; although, the difference was small ( 0.2 days) and of little productive importance. Regarding subsequent performance, some studies showed an increased ovulation rate (14.8 vs. 13.0$)$ and a consequent increased litter ( 10.0 vs. 8.8$)$ in primiparous females consuming more feed $(4 \mathrm{~kg} /$ day) during the weaning interval compared with females receiving $1.5 \mathrm{~kg} /$ day (KING \& WILLIAMS, 1984). However, these variables were not affected by the amount of feed $(1.8,2.3,3.6$, and $4.5 \mathrm{~kg} /$ day) supplied to the multiparous sows (BROOKS et al., 1975).

Differences between studies evaluating the interaction between reproductive performance and feed intake on the WEI can be associated to the lack of evaluation of the percentage of weight loss during lactation. THAKER \& BILKEI (2005) reported that sows can lose between 5 and $>20 \%$ of weight during lactation, and reported that the WEI duration increased when the weight loss exceeded $5 \%$ for primiparous and $10 \%$ for multiparous sows. In addition, those authors reported a reduced litter size after $10 \%$ weight loss, regardless of $\mathrm{BO}$. This was possibly due to a greater loss of protein during lactation, which negatively impacted the follicle size at weaning (CLOWES et al., 2003; YANG et al., 2009). BAIDOO et al. (1992) studied free and restricted feeding during lactation and the WEI (6 and $3 \mathrm{~kg} /$ day). They suggested that a higher diet plan in the postweaning period can benefit sows that are not subject to correct management during lactation. Thus, the higher feed supply to sows in previous decades was important to recover the subsequent decrease in reproductive performance caused by excessive weight loss during lactation, an effect that is more evident in young sows.

The relationship between nutrition and reproduction remains unclear; however, changing the amount or type of feed during the WEI can also affect the duration of this period and the subsequent performance, since much of the follicular growth will occur during the WEI. Normally, multiparous sows at weaning have follicles with a mean diameter of 3 $\mathrm{mm}$, which grow to a mean of $8 \mathrm{~mm}$ before ovulation (SOEDE et al., 2011). According to PRUNIER \& QUESNEL (2000), nutrition can influence reproduction by stimulating the hypothalamicpituitary axis, thus changing gonadotropin release (follicle stimulating hormone and luteinizing hormone), and by direct action on the ovaries via metabolic mediators such as insulin and insulin-like growth factor I (IGF-1). Gonadotropin release and mediator concentrations can be influenced by the amount of feed ingested and/or the energy source of the diet. This was demonstrated by ZAK et al. (1997), VAN DEN BRAND et al. (2000) and CHEN et al. (2016), who reported changes in LH pulsatility, and in the concentration of postprandial plasma insulin, IGF-1, and glucose in females receiving different amounts of feed or energy sources. In summary, changes in gonadotropin and mediator release due to nutrition may influence folliculogenesis and ovarian activity, affecting WEI duration (CHEN et al., 2016), 
follicular development (VAN DEN BRAND et al. 2000), and embryonic survival (ZAK et al., 1997). However, presently, neither the amount (4.3 or 2.75 $\mathrm{kg} /$ day) nor type of feed (gestation or lactation) used during WEI impacts the follicular development of sows (GIANLUPPI et al., 2020).

In addition, for sows with a body weight equal to or greater than 2.75 (the ideal is 3), 2.7 $\mathrm{kg} /$ day of gestation feed $(0.55 \%$ digestible lysine and 3.2 Mcal ME/ $\mathrm{kg}$ ) during WEI was sufficient to obtain a satisfactory birth rate and total birth results (GRAHAM et al., 2015). Even when females with a low Caliper score (less than 12) were evaluated, $2.75 \mathrm{~kg} /$ day of gestation feed (0.62 digestible lysine and $3.26 \mathrm{Mcal} \mathrm{ME} / \mathrm{kg}$ ) was adequate to guarantee subsequent performance compared to the use of different feeds and/or greater amounts (GIANLUPPI et al., 2020). Likewise, in the present study, $2.75 \mathrm{~kg} /$ day of gestation feed (0.69 digestible lysine and 3.28 Mcal ME $/ \mathrm{kg}$ ) was sufficient to ensure a good birth rate and total birth results. Additionally, there was no difference in the weight of the animals; although, there was a trend for a greater number of live births for sows consuming smaller amounts of feed, and for sows consuming gestational feed. However, this effect was due to differences in the number of mummified fetuses, probably related to other effects that could not be explained by the results of this study. In addition, the difference in the number of live births also influenced the total mean weight of live births.

\section{CONCLUSION}

A supply of $3.75 \mathrm{~kg} /$ day or the use of a more energetic feed (lactation) during the WEI did not improve the reproductive performance of the subsequent cycle of sows in good body condition.

\section{ACKNOWLEDGMENTS}

We thank Copercampos Cooperative, especially Lúcio Marsal Rosa de Almeida and all employees of Granja dos Pinheiros (Campos Novos, Santa Catarina, Brazil) for providing the facilities required for this study; and Agroceres PIC for support in the execution of this project; and was financed in part by the Coordenação de Aperfeiçoamento de Pessoal de Nível Superior (CAPES), Brasil - Finance code 001.

\section{BIOETHICS AND BIOSSECURITY COMMITTEE APPROVAL}

All procedures were approved by the Animal Ethics Committee of the Agricultural Sciences Department of the Federal University of Paraná.

\section{DECLARATION OF CONFLICT OF INTERESTS}

The authors declare no conflict of interest. The funding sponsors had no role in the design of the study; in the collection, analyses, or interpretation of data; in the writing of the manuscript, and in the decision to publish the results.

\section{AUTHORS' CONTRIBUTIONS}

All authors contributed equally to designing and preparing the manuscript. All authors critically reviewed the manuscript and approved the final version.

\section{REFERENCES}

AHERNE, F. X.; KIRKWOOD, R. N. Nutrition and sow prolificacy. Journal of Reproduction and Reproduction, v.33, p.161-183, 1985. Available from: <https://www.researchgate. net/publication/19250763_Nutrition_and_sow_prolificacy>. Accessed: Nov. 15, 2019.

BAIDOO, S. K. et al. Effect of feed intake during lactation and after weaning on sow reproductive performance. Canadian Journal of Animal Science, v.72, p.911-917, 1992. Available from: $<$ https://www.nrcresearchpress.com/doi/pdf/10.4141/cjas92-103>. Accessed: Jul. 7, 2019. doi: 10.4141/cjas92-103.

BROOKS, P. H.; COLE, D. J. A. Studies in sow reproduction. 1. Effect of nutrition between weaning and remating on the reproductive performance of primiparous sows. Animal Production, v.15, p.259-264, 1972. Available from: $<$ https://doi. org/10.1017/S000335610001151X>. Accessed: Jul. 7, 2019. doi: $10.1017 / \mathrm{S} 000335610001151 \mathrm{X}$.

BROOKS, P. H. et al. Studies in sow reproduction. 3. Effect of nutrition between weaning and remating on the reproductive performance of multiparous sows. Animal Production, v.20, p.427-432, 1975. Available from: <https://doi.org/10.1017/ S0003356100041209>. Accessed: Jul. 7, 2019. doi: 10.1017/ S0003356100041209.

CHEN, X. et al. Interactive effects of dietary protein concentration and aflatoxin B1 on performance, nutrient digestibility, and gut health in broiler chicks. Poultry Science, v.95, p.1312-1325, 2016. Available from: <https://doi.org/10.3382/ps/pew022>. Accessed: Aug. 10, 2019. doi: 10.3382/ps/pew022.

CLOWES, E. J. et al. Selective protein loss in lactating sows is associated with reduced litter growth and ovarian function. Journal of Animal Science, v.81, p.753-764, 2003. Available from: <https://doi.org/10.2527/2003.813753x>. Accessed: Aug. 10, 2019. doi: $10.2527 / 2003.813753 x$.

FAHMY, M. H.; DUFOUR, J.J. Effects of post-weaning stress and feeding management on return to estrus and reproductive traits during early pregnancy in swine. Animal Production, v.23, p.103-110, 1976. Available from: <https://doi.org/10.1017/ S0003356100031147>. Accessed: Jul. 10, 2019. doi: 10.1017/ S0003356100031147.

GIANLUPPI, R. D. F. et al. Effects of different amounts and type of diet during weaning-to-estrus interval on reproductive performance of primiparous and multiparous sows. Animal, p.1-10, 2020. 
Available from: <https://doi.org/10.1017/S175173112000049X>. Accessed: Mar. 30, 2020. doi: 10.1017/S175173112000049X

GRAHAM, A. A. et al. Impact of feeding level post weaning on wean to estrus interval, conception and farrowing rates and subsequent farrowing performance. 2015. Available from: $<$ https://asas.confex.com/asas/mw15/webprogram/Paper11486. html >. Accessed: Sep. 15, 2019.

JONG, E. et al. Management factors associated with sow reproductive performance after weaning. Reproduction in Domestic Animals, v.48, p.435-440, 2013. Available from: $<$ https://doi.org/10.4148/2378-5977.1123>. Accessed: Sep. 15, 2019. doi: $10.4148 / 2378-5977.1123$.

KENWARD, M. G.; ROGER, J. H. Small sample inference for fixed effects from restricted maximum likelihood. Biometrics, v.53, p.983-997, 1997. Available from: <https:// doi.org/10.2307/2533558>. Accessed: Sep. 15, 2019. doi: $10.2307 / 2533558$.

KING, R. H.; WILLIAMS, I. H. The effect of nutrition on the reproductive performance of first-litter sows 1. Feeding level during lactation, and between weaning and mating. Animal Production, v.38, p.241-247, 1984. Available from: < https://doi. org/10.1017/S0003356100002233>. Accessed: Jul. 20, 2019. doi: $10.1017 / \mathrm{S} 0003356100002233$

KNAUER, M. T.; BAITINGER, D. J. The sow body condition caliper. American Society of Agricultural and Biological Engineers, v.31, n.2, p.175-178, 2015. Available from: <https:// elibrary.asabe.org/abstract.asp?aid=45455>. Accessed: Jun. 24, 2019.

POLEZE, E. et al. Consequences of variation in weaning-to-estrus interval on reproductive performance of swine females. Livestock Science, v.103, p.124-130, 2006. Available from: <https://doi. org/10.1016/j.livsci.2006.02.007>. Accessed: Jul. 10, 2019. doi: 10.1016/j.livsci.2006.02.007.

PRUNIER, A.; QUESNEL, H. Nutritional influences on the hormonal control of reproduction in female pigs. Livestock Production Science, v.63, p.1-16, 2000. Available from: <https:// doi.org/10.1016/S0301-6226(99)00113-X>. Accessed: Jul. 20, 2019. doi: 10.1016/S0301-6226(99)00113-X.

SOEDE, N. M. et al. Reproductive cycles in pigs. Animal Reproduction Science, v.124, p.251-258, 2011. Available from:
$<$ https://doi.org/10.1016/j.anireprosci.2011.02.025>. Accessed: Jun. 24, 2019. doi: 10.1016/j.anireprosci.2011.02.025.

STROUP, W.W. Generalized linear mixed models: modern concepts, methods and applications. CRC press, 2012.

THAKER, M. Y. C.; BILKEI, G. Lactation weight loss influences subsequent reproductive performance of sows. Animal Reproduction Science, v.88, p.309-318, 2005. Available from: $<$ https://doi.org/10.1016/j.anireprosci.2004.10.001>. Accessed: Jul. 10, 2019. doi: 10.1016/j.anireprosci.2004.10.001.

TRIBBLE, L. F.; ORR, D. E. Effect of feeding level after weaning on reproduction in sows. Journal of Animal Science, v.55, p.608-612, 1982. Available from: <https://doi.org/10.2527/ jas1982.553608x>. Accessed: Aug. 20, 2019. doi: 10.2527/ jas1982.553608x

VAN DEN BRAND, H. et al. Dietary energy source at two feeding levels during lactation of primiparous sows: I. Effects on glucose, insulin, and luteinizing hormone and on follicle development, weaning-to-oestrus interval, and ovulation. Journal of Animal Science, v.78, p.396-404, 2000. Available from: <https://doi. org. 10.2527/2000.782396x>. Accessed: Jul. 7, 2019. doi: $10.2527 / 2000.782396 x$.

VANGROENWEGHE, F. et al. An evaluation of gonadotropinreleasing hormone analogue administered to gilts and sows on subsequent reproductive performance and piglet birth weight. Porcine Health Management, v.2, p.1-7, 2016. Available from: $<$ https://doi.org/10.1186/s40813-016-0018-1>. Accessed: Jun. 24, 2019. doi: 10.1186/s40813-016-0018-1.

YANG, Y. et al. Effects of lysine intake during late gestation and lactation on blood metabolites, hormones, milk composition and reproductive performance in primiparous and multiparous sows. Animal Reproduction Science, v.112, p.199-214, 2009. Available from: <https://doi.org/10.1016/j. anireprosci.2008.04.031>. Accessed: Jul. 10, 2019. doi: 10.1016/j.anireprosci.2008.04.031.

ZAK, L. et al. Pattern of feed intake and associated metabolic and endocrine changes differentially affect postweaning fertility in primiparous lactating sows. Journal of Animal Science, v.75, n.1, p.208-216, 1997. Available from: <https:// doi.org/10.2527/1997.751208x>. Accessed: Aug. 20, 2019. doi: $10.2527 / 1997.751208 x$. 